\title{
Erwinia chrysanthemi Burk., McFadden \& Dimock: A bacterial whorl and stalk rot pathogen of sorghum [Sorghum bicolor (L.) Moench.]'
}

\author{
Paul R. Hepperly and Ezequiel Ramos-Dáila
}

\begin{abstract}
A foul smelling soft rot of the upper stalk and leaves of sorghum was observed in Isabela, Puerto Rico, during the summer of 1985. The bacterium from infected roting sorghum whorls was isolated in pure culture and inoculated to sorghum, maize (Zea mays L.), and sugarcane (Saccharum officinarum L.) in the field and to potato (Solanum fuberosum L.) and pineapple [Ananas comosus (L.) Merr.] in vitro. Results of parhogenicity and 23 phenolypic lests suggested Erwinia chrysanthemi p.v. zeae Burk., McFadden \& Dimock as the causal agent of the bacterial whorl blight and stalk rot of sorghum. Twenty-two anfibiotics were tested for in vitro control of our strain of the whorl blight pathogen. Zones of inhibition around antibiotic impregnated discs on bacteria, seeded on Muller Hinton Agar, showed high pathogen sensitivity to senociclin, chloramphenicol, kanamycin, gentamicin, carbenicillin, cefotaximine, tetracycline, amikacin, and tobramycin. Members of the penicillin family appeared ineffective for controlling this bacterium. TAM 428 and SC 120, dwarf sorghums with moist sweet stems, were severely damaged when fungicide treated. Mean incidence of visible bacterial whorl blight reached $25 \%$. Yield losses ranged from 34 to $56 \%$. Dry stemmed sorghums, SC 307 and SC 212, showed less than $5 \%$ whorl blight and no yield loss.
\end{abstract}

\section{INTRODUCTION}

Few bacteria are known as pathogens of sorghum [Sorghum bicolor (L.) Moench.]. Pseudomonas andropogoni, P. syringae, and Xanthomonas holeicola are the most common bacterial pathogens of the crop (6). Significant losses from bacterial diseases on sorghum are rare (9). It has been suggested that bacterial diseases on sorghum largely go unnoticed because of inadequate diagnosis (9).

During the summer of 1985 , a foul smelling soft rot of sorghum whorls reached epidemic proportions in experiments on sorghum rust in Isabela, Puerto Rico. Efforts were made to describe the disease, identify the pathogen, calculate losses, and determine factors associated with the outbreak. We will report on those studies and on the screening of antibiotics against the causal organism.

2 Manuseript submitted to Editorial Board September 17, 1986.

${ }^{2}$ Research Plant Pathologist, USDA-ARS-SAA-TARS, Mayagiez, Puerto Rico and Registered Medical Teehnologist, respectively. 


\section{MATERIALS AND METHODS}

All field studies were conducted at the Isabela farm of the Tropical Agriculture Research Station, U.S. Department of Agriculture, Agricultural Research Service, South Atlantic Area at Mayagiez, Puerto Rico. Laboratory studies were conducted at the Plant Pathology Laboratory of the same station.

The test bacterium was isolated from 70-day-old plants of SC 120 sorghum showing typical whorl blight symptoms. Infeeted materials were surface sterilized ( $0.5 \% \mathrm{NaOCl}$ for $1 \mathrm{~min})$, rinsed in sterile distilled water, and minced in droplets of sterile distilled water before we streaked the suspension on plates of glucose yeast agar (GYA), GYA + $5 \%$ sodium chloride, GYA $+2 \%$ calcium carbonate, potato dextrose and potato sucrose agars. Plates were incubated at $27^{\circ} \mathrm{C}, 37^{\circ} \mathrm{C}$, or $40^{\circ} \mathrm{C}$ to determine colony characteristics and response to incubation temperature.

Biochemical and physiological tests (phenotypic tests) were conducted with 24 to 48 -hour-old colonies. Pure cultures on 9-em diameter plates of glucose yeast calcium carbonate agar incubated at $27^{\circ} \mathrm{C}$ were rinsed and suspended in $10 \mathrm{ml}$ sterile distilled water. Test solutions were made at $1.0 \%(\mathrm{w} / \mathrm{v})$ concentration of both carbon and nitrogen sources diluted in $0.1 \mathrm{~N}$ solutions of both mono and dibasic potassium phosphate. Tests were made in test tubes filled with $10 \mathrm{ml}$ aliquots replicated 3 times. Each tube was inoculated with $0.05 \mathrm{ml}$ (one droplet) of bacterial suspension. Catalase, $\mathrm{H}_{2} \mathrm{~S}$ production, and gas and acid from glucose were tested as described by Dye (3). The gram stain utilized was the Hucker modification (8). Tests for phosphatase, pectin degradation, gelatin liquefaction, and reducing substances from sucrose were performed as described by Kelman and Dickey (5). Cell morphology was determined with bright field oil immersion microscopy $(\times 1,000)$. Anaerobic growth was tested in phosphate buffered aqueous solution containing $1 \%$ of each glucose and yeast. Test aliquots were covered with $2 \mathrm{~cm}$ of sterile mineral oil, and test tubes were sealed with rubber stoppers. Nitrate reduction was tested by the method deseribed by Bradbury (1). Indole production was tested as described by Lelliott (7) and lecithinase and hydrolysis of starch were determined in phosphate amended aqueous solution of $1 \%$ potassium nitrate with addition of either $1 \%$ soybean lecithin or potato starch as sole carbon sources. Clearing of starch solution or erosion of soybean lecithin granules were considered positive reactions.

Three- to eight-week-old field plants of common sugarcane, sorghum (FS25A and Haygrazer, commercial forage hybrids, and B73, commercial inbred parental line) and corn (B7) were inoculated by a modified Hartman and Kelman method (4). An aqueous bacterial suspension $\left(7 \times 10^{7}\right.$ cells $\left./ \mathrm{ml}\right)$ was amended with $0.7 \%$ polyethylene sorbitan monoster- 
ate (Tween $60 \mathrm{RT}$, Sigma Chem., Co., St. Louis) and aliquots of $10 \mathrm{ml}$ were pipetted in the whor of test plants. The foliage was trimmed, and the inoculated whorl covered with a plastic bag, which was stapled elosed to maintain high humidity. Control plants received the same treatment with distilled water. To inoculate Red Spanish pineapple and common potato tubers, we seraped $E$. chrysanthemi from colonies on glucose yeast calcium carbonate agar incubated at $27^{\circ} \mathrm{C}$ or $37^{\circ} \mathrm{C}$ with sterilized toothpicks and we inserted the bacteria-covered toothpicks in the fruits and tubers.

Effect of fungicides on bacterial and stalk rot and yield losses were calculated in a field experiment featuring four sorghum lines (SC 307, SC 212, TAM 428 and SC 120). Three fungicides, i.e. mancozeb, oxycarboxin, triadimefon, and the non-treated (check) ${ }^{3}$ were replicated three times and arranged in a randomized block design. Fungicides were applied at the boot stage and 2 weeks thereafter. Fungicide rates were 2, 1, and $0.5 \mathrm{~kg}$ a.i./ha spray for mancozeb, oxycarboxin, and triadimefon, respectively. Whorl blight readings (incidence) were taken at 14 days after flowering and at physiological maturity. Yield was determined for each plot $(6 \mathrm{~m} \times 4 \mathrm{~m})$ from a sample of 12 random panicles bagged at first. flowering to prevent bird predation. Grain was harvested at physiological maturity, dried, weighed, and moisture tested. Grain yields were adjusted to $14 \%$ moisture. Bacterial infection was by natural inoculation. All data were analyzed for variance.

Plant moisture and sweetness were determined subjectively. Plants were cut laterally 14 days after flowering to judge internal stem moisture, and the 3rd internode was split longitudinally, to test sweetness and moistness. Notes were also taken of midrib appearance, and lines were classified as $D D$ (dry midrib) or $d d$ (moist or dull midrib).

Twenty-two antibiotics were screened by commercially prepared test discs impregnated with antibiotics at test concentrations of 2 to $300 \mu \mathrm{g} /$ $\mathrm{ml}$. Thirty $\mu \mathrm{g} / \mathrm{ml}$ was the most common antibiotic concentration used. Mueller Hinton agar (Difco, Detroit, MI) in 15-cm test culture plates was seeded with the test bacteria isolated from sorghum. Eleven discs were placed on each plate. Plates were ineubated at $37^{\circ} \mathrm{C}$ for 24 hours and the

${ }^{3}$ Mancozeb ( $16 \%$ manganese, $2 \%$ zinc and $62 \%$ ethylenebisdithiocarbamate) as Dithane M-45 80W registered trademark, Rohm and Haas Co., Philadelphia, PA 19105; oxycarboxin (5,6-dihydro-2-methyl-1,4-oxathrin-3-carboxanilide-4,4-dioxide) as Plantvax 75W registered trademark, Uniroyal Chemical Co., Nuugatuck, CT 06770; and triadimefon 1-(4chlorophenoxy)-3,3-dimethyl-1-(1H-1,2,4-triazol-1-xl)-2-butanose as Bayleton 50W registered trademark, Mobay Chemical Co., Kansas City, MO 64120.

Trade names in this publication are used only to provide specific information. Mention of a trade name does not constitute a warranty of equipment or materials by the Agrieultural Experiment Station of the University of Puerto Rico, nor is this mention a statement of preference over other equipment or materials. 
diameters of zones free from bacteria were measured. According to the zone diameter, the bacterium was categorized either very sensitive (18 or more $\mathrm{mm}$ ), moderately sensitive $(9-17 \mathrm{~mm}$ ), or insensitive (less than $9 \mathrm{~mm})$ to the test antibiotic.

\section{RESULTS}

Table 1 shows the results of phenotypic tests for the sorghum whorl and stem pathogen. The bacterium was detected microscopically in ooze tests and purified by streak plating. Hucker's Gram Stain revealed a gram negative bacillary or rod-shaped bacterium. This organism grew anaerobically with production of gas from glucose yeast solution, suggesting that it was a species of Emvinia. Microscopic observation of bacterial movement and lateral diffusion on stab inoculated semi-solid media suggested a highly motile bacterium. The bacterium grew on mineral salts with potassium nitrate as a sole $\mathrm{N}$-souree and glucose as a sole carbon source. Improved growth was found on potato dextrose agar (PDA), glucose yeast agar (GYA), and GYA + $2 \%$ calcium carbonate. Brown coloration was produced on potato sucrose agar after 3 to 5 days. Growth at $40^{\circ} \mathrm{C}$, gas production from glucose, and positive reactions for

TABLE 1.-Phenotypic responses of Erwinia chrysanthemi p.v. zeae isolated from whorl blighted sorghum (Sorghum bicolor) in Isabela, Puerto Rico

\begin{tabular}{lc}
\hline \multicolumn{1}{c}{ Criterion } & Response \\
\hline Fried Egg Shape Colony on Potato Dextrose Agar & + \\
Rod Shape Particle & + \\
Motility in Semi-solid Media & + \\
Gram Stain & - \\
Blue Coloration on Glueose-Yeast-Calcium Carbonate Agar & + \\
Brown Coloration on Potato Sucrose Agar & + \\
Anaerobic Growth & + \\
Gas and Acid from Glucose & + \\
Starch Hydrolysis & + \\
Pectin Hydrolysis & + \\
Sucrose Reduction & + \\
KNO ${ }_{3}$ Reduction & + \\
Catalase Production & + \\
Phosphatase Production & + \\
Lecithinase Production & + \\
HoS Produetion & + \\
Indole Production & + \\
${ }^{1}$ Glutamate Utilization & + \\
IEthanol Utilization & + \\
'Proline Utilization & + \\
Growth at $40^{\circ}$ & + \\
Gelatin Hydrolysis & + \\
\hline
\end{tabular}

Used for pathovar determination according to Thompson et al. (9). 
catalase, phosphatase, and lecithinase pathovar zeae was suggested by positive utilization of proline, glutamate, and ehtanol as sole C-sources (9).

Field tests showed that sorghum and corn become susceptible at approximately 30 days after planting. This stage, early whorl stage, marks the initiation of panicle or tassel development and, more precipitation and moisture are accumulated in the whorl than in seedling stages. Natural infection appeared to decrease from 30 to 60 days after planting.

Whorl rot of corn and sorghum developed 2 days after inoculation when conditions favored bacterial growth (table 2). Wilting of the upperand inner-most leaves was the first symptom. When infected leaves were pulled, they separated from the stalk at the point of intense bacterial rot near the stem's apex. The disjointed apex appeared as a mushy foul smelling whip. The following three stages of symptoms were observed: flaccid leaves (F), greasy leaves (G) and finally withered leaves (W) (fig. 1A). Stalk rot appeared to proceed from the apical center and move downward and laterally. Genotypes with resistance showed marked compartmentalization of the rot. In sorghum, red plant pigments $(P)$ are often deposited at the margins of healthy $(\mathrm{H})$ and soft rotted (SR) tissue (fig. 1B). These pigments were not found in corn. In both corn and sorghum, basal tillering was intensely stimulated after the plants toppled. These tillers were seldom infected but they did not appear to produce economic grain yield.

In sugarcane the inner whorl leaves showed a dry nonspreading tip necrosis and the basal leaf was mottled (table 2). In contrast to corn or sorghum no stem deterioration was found.

In the laboratory, soft rots of potato and pineapple were most evident at high temperature, $37^{\circ} \mathrm{C}$ incubation (table 2). Rot was greater in inoculated potato than in pineapple. No rot was observed in noninoculated controls of either plant.

Moist stemmed dwarf grain sorghum sprayed with fungicide showed pronounced bacterial whorl blight from natural infection (table 3). Dry stemmed dwarf sorghums, SC 212 and SC 307 , showed insignificant infection regardless of fungicide treatment. TAM 428 and SC 120 had significant $(\mathrm{P}=0.01)$ yield losses, 33 to $56 \%$, respectively, associated with dramatically increased whorl blight after fungicide applications. The susceptible lines, TAM 428 and SC 120 , showed a moist plant character ( $d d$ ) compared to the dry character $(D D)$ of SC 307 and SC 212 (fig. 2A-D). In all genotypes were 3 or 4 dwarf.

The sensitivity of our strain of $E$. chrysanthemi var. zeae from sorghum to 22 antibiotics was measured (table 4). Eight antibiotics were highly effective, 6 were moderately effective, and 8 were ineffective in controlling the bacterium. Members of the penicillin family appeared gen- 


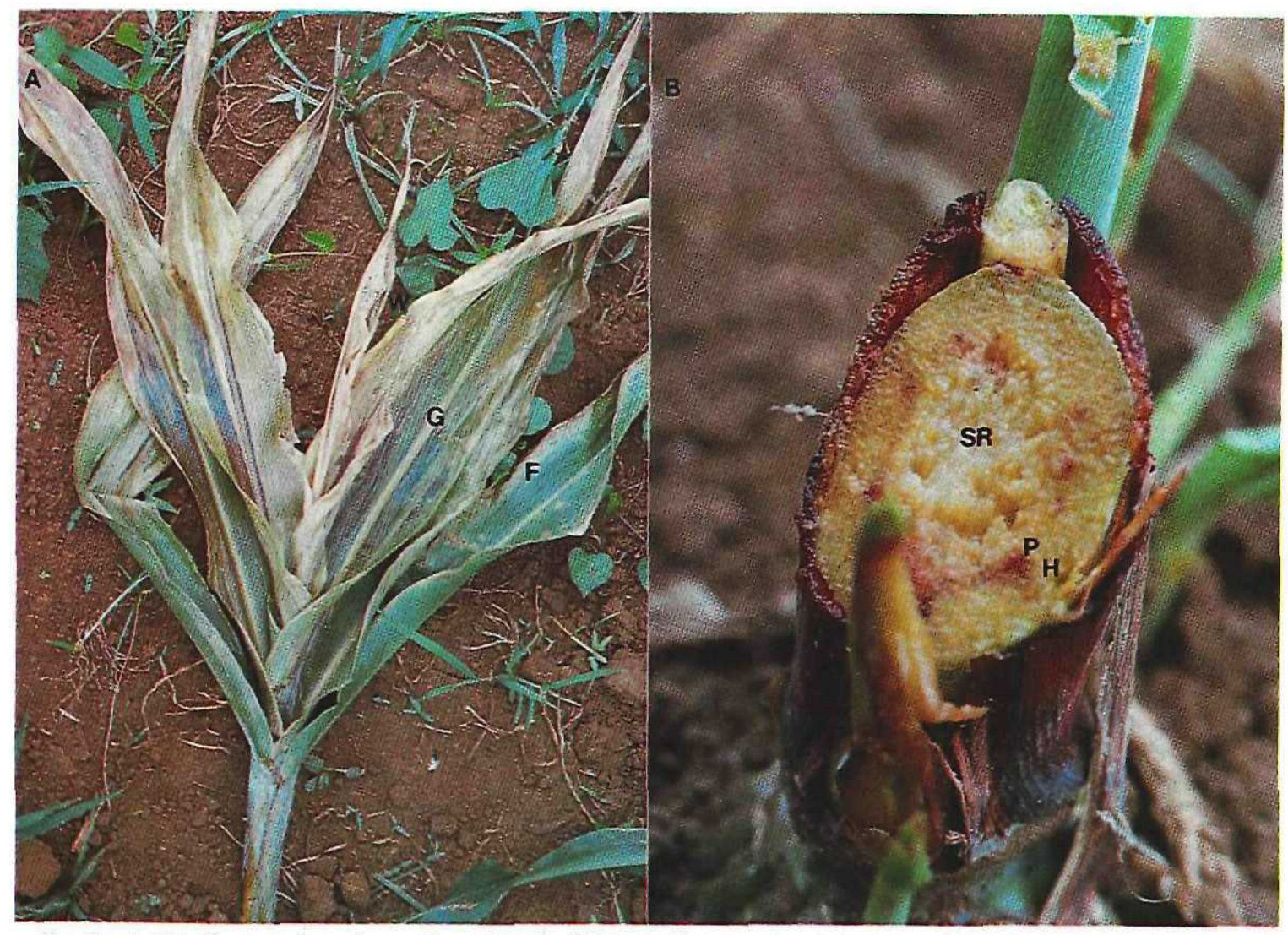

FIG. 1.-A. Note the typical symptoms of bacterial whorl blight in SC 120 sorghum in boot stage. The oldest symptoms appear at the plant's apex where leaves are withered $(\mathrm{W})$. On lower leaves a greasy looking deterioration $(\mathrm{G})$ is found. The lowest outermost leaves show flaccidity $(F)$ the first symptom of bacterial whorl blight. B. Severe stalk root spreads downward and laterally from the apex center. Note a severe case of stalk rot obliquely cross-sectioned at the basal internode of SC 120 sorghum. Bacterial soft rot (SR) is found in the stalk center. Purple sorghum pigment $(\mathrm{P})$ is formed at the margin of healthy $(\mathrm{H})$ and rotted tissues. 


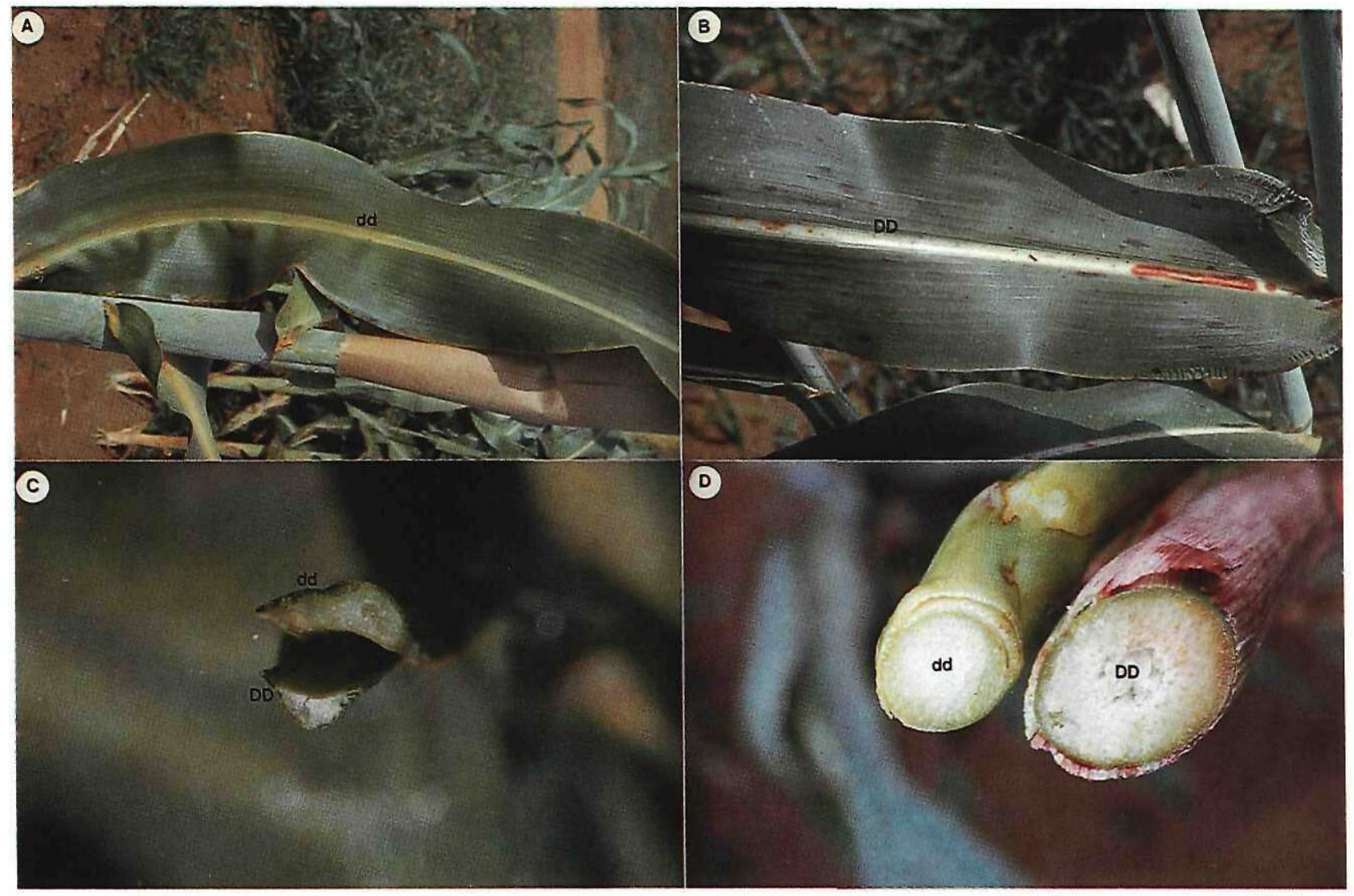

FIG. 2.-A. The moist plant character $(d d)$ is denoted by a dull greenish midrib as in SC 120 sorghum leaves. B. The white midrib denotes the dry plant character $(D D)$ as seen in SC 212 sorghum leaves. C. The cross sections of the midribs from $2 \mathrm{~A}$ and $2 \mathrm{~B}$ show moisture differences in moist ( $d d$ ) and dry $(D D)$ plant types. D. Stem juiciness in moist (dd) and dry $(D D)$ plant types as shown by cross sections of SC 120 and SC 212 stems. Only moist plants showed marked bacterial whorl bacterial following fungicide applications. 
TABLE 2.-Pathogenicity of Erwinia chrysanthemi p.v. zeae from whon blighted songhum (Sorghum bicolor) toward sorghum, corn (Zea mays), sugarcane (Sacharum officinarum), potato (Solanum tuberosum), and pinectpple (Ananas comosus) in field and laboratory tests in western Puerto Rico'

\begin{tabular}{|c|c|}
\hline Test plant & Symptoms \\
\hline Sorghum & $\begin{array}{l}\text { FS25A and Haygrazer sorghum hybrid showed a rapid whorl decay in } \\
\text { 30-day -old seedlings. }\end{array}$ \\
\hline Corn & B73 shows a rapid whorl rate on plants less than 70 days old. \\
\hline Sugarcane & $\begin{array}{l}\text { Dry leaf tip neerosis and basal leaf mottle when } 60 \text {-day-old rattoon whorls } \\
\text { were inoculated. }\end{array}$ \\
\hline Potato & $\begin{array}{l}\text { Slight tuber-piece rot at } 27^{\circ} \mathrm{C} \text {. Rapid and marked tuber-piece soft rot } \\
\text { at } 37^{\circ} \mathrm{C} \text {. }\end{array}$ \\
\hline Pineapple & Dry leaf necrosis without rotting at $27^{\circ} \mathrm{C}$. Slight soft rot of fruits at $37^{\circ} \mathrm{C}$. \\
\hline
\end{tabular}

${ }^{1}$ Inoeulum consisted of $7 \times 10^{7}$ bacteria/ml from 1-day-old colonies on glucose-yeast-calcium carbonate agar at $35^{\circ} \mathrm{C}$. Bacteria were diluted in sterile tap water amended with Tween 60 (polyoxyethylene-sorbitan monostearate) at $0.7 \%$. Ten $\mathrm{ml}$ of inoculum was added to each site. Inoculation courts were covered with plastic bags to maintain high relative humidity.

TABLE 3.-Incidence of visible whorl blight and blight associated yield losses of 4 sorghum lines treated with 3 fungicides or nontreated in Isabela, Puerto Rico

\begin{tabular}{|c|c|c|c|c|c|}
\hline Treatment & $\begin{array}{c}\text { Dosage } \\
\text { (kgai./ha) }\end{array}$ & $\begin{array}{l}\text { Sorghtum } \\
\text { line }\end{array}$ & $\begin{array}{l}\text { Percentage } \\
\text { ineidence }\end{array}$ & Sig. & $\begin{array}{c}\text { Percentage }^{1} \\
\text { yield } \\
\text { loss }\end{array}$ \\
\hline Triadimefon & 0.50 & $\begin{array}{l}\operatorname{SC} 307^{2} \\
\operatorname{SC} 212^{2}\end{array}$ & $\begin{array}{l}3.7 \\
0.3\end{array}$ & $\begin{array}{l}\text { NS } \\
\text { NS }\end{array}$ & $\begin{array}{l}\text { NS } \\
\text { NS }\end{array}$ \\
\hline Bayleton $50 W^{\mathrm{RT}}$ & & $\begin{array}{l}\text { TAM } 428^{4} \\
\text { SC } 120^{\circ}\end{array}$ & $\begin{array}{l}16.0 \\
10.3\end{array}$ & *末b & $\begin{array}{l}51.7 \\
33.5\end{array}$ \\
\hline Oxycarboxin & 1.00 & $\begin{array}{l}\text { SC } 307 \\
\text { SC } 212\end{array}$ & $\begin{array}{l}3.7 \\
0.3\end{array}$ & $\begin{array}{l}\text { NS } \\
\text { NS }\end{array}$ & $\begin{array}{l}\text { NS } \\
\text { NS }\end{array}$ \\
\hline Plantvax $75 \mathrm{~W}^{\mathrm{Hx}}$ & & $\begin{array}{l}\text { TAM } 428 \\
\text { SC } 120\end{array}$ & $\begin{array}{l}26.0 \\
25.0\end{array}$ & $* *$ & $\begin{array}{l}54.3 \\
55.2\end{array}$ \\
\hline Maneozeb & 2.00 & $\begin{array}{l}\text { SC } 307 \\
\text { SC } 212\end{array}$ & $\begin{array}{l}3.0 \\
0.7\end{array}$ & $\begin{array}{l}\text { NS } \\
\text { NS }\end{array}$ & $\begin{array}{l}\text { NS } \\
\text { NS }\end{array}$ \\
\hline Dithane M-45 80W & & $\begin{array}{l}\text { TAM } 428 \\
\text { SC } 120\end{array}$ & $\begin{array}{l}19.6 \\
24.3\end{array}$ & $* * *$ & $\begin{array}{l}46.1 \\
56.3\end{array}$ \\
\hline Nontreated & & $\begin{array}{l}\text { SC } 307 \\
\text { SC } 212 \\
\text { TAM } 428 \\
\text { SC } 120\end{array}$ & $\begin{array}{l}0.0 \\
0.0 \\
0.0 \\
0.0\end{array}$ & $\begin{array}{l}- \\
- \\
-\end{array}$ & $\begin{array}{l}- \\
- \\
-\end{array}$ \\
\hline
\end{tabular}

Percentage loss $=$ (Nontreated - Treated-Nontreated $)(100)$.

${ }^{2}$ Dry midrib, very slightly sweet, dry stemmed 4 dwarf.

${ }^{3}$ Diy midrib, very dry insipid stemmed 4 dwarf.

${ }^{4}$ Dull midrib, sweet moist stem, 3 dwarf.

"Dull midrib, very sweet moist stem, 4 dwarf.

- Incidence significant $(P=0,01)$ when compared to that of the nontreated control: NS

- Not statistically different, FLSD and $* *=$ Sig. FLSD, $P=0.01$. 
TABLE 4.-Sensitivity of Erwinia chrysanthemi var. zeae to vasious antibiotics based on inhibition zones around antibiotic impregnated discs on Muller Hinton aga seeded with E. chrysanthemi var, zeae from sorghum ${ }^{1}$

\begin{tabular}{lccc}
\hline \multicolumn{1}{c}{ Antibiotic } & $\begin{array}{c}\text { Dosage } \\
(\mu \mathrm{g} / \mathrm{ml})\end{array}$ & $\begin{array}{c}\text { Diameter } \\
\text { Inhibition zone } \\
(\mathrm{mm})\end{array}$ & Category $^{2}$ \\
\hline Sennociclin & 25 & 25 & VS \\
Chloramphenicol & 30 & 24 & VS \\
Kanamycin & 30 & 21 & VS \\
Gentamycin & 10 & 20 & VS \\
Carbenicillin & 100 & 20 & VS \\
Amikacin & 30 & 19 & VS \\
Tetracycline & 30 & 18 & VS \\
Tobramycin & 10 & 18 & VS \\
Nalidixie Acid & 30 & 16 & MS \\
Furaltadone & 300 & 15 & MS \\
Neomycin & 30 & 14 & MS \\
Erythromycin & 15 & 13 & MS \\
Polymyxin B & 300 & 10 & MS \\
Colistin & 10 & 9 & MS \\
Cephalexin & 30 & 0 & IS \\
Cefoxitin & 30 & 0 & IS \\
Penicillin & 10 & 0 & IS \\
Lincomycin & 2 & 0 & IS \\
Cleocin & 2 & 0 & IS \\
Ampicillin & 10 & 0 & IS \\
Oxacillin & 1 & 0 & IS \\
Novobiocin & 30 & 0 & IS \\
\hline T & & & \\
\hline
\end{tabular}

${ }^{1}$ Incubation of 24 hours at $37^{\circ} \mathrm{C}$.

$2 \mathrm{VS}=$ Very sensitive.

MS = Moderately sensitive.

IS = Insensitive.

erally ineffective with the exception of carbenicillin. Carbenicillin was effective at $100 \mu \mathrm{g} / \mathrm{ml}$. Other penicillins were tested at $30 \mu \mathrm{g} / \mathrm{ml}$ or less. Tetracycline-like antibiotics appeared highly effective at the doses tested.

\section{DISCUSSION}

Substantial yield losses were recorded when dwarf moist stemmed sorghums were predisposed to natural infection by Erwinia chrysonthemi p.v. zeae after fungieide applications at boot stage and two weeks thereafter. Erwinia chrysanthemi p.v. zeae has not been previously reported in Puerto Rico nor as a natural pathogen of sorghum. Pérez isolated $E$. chrysanthemi from diseased Dieffenbachia maculata (Lodd.) G. Don. in Puerto Rico (2).

Intensively managed sorghum can suffer sizeable yield and quality losses from fungal leaf blights and seed molds particularly under humid 
tropical and subtropical environments. Our 1985 experiments on fungicide control of foliar diseases led to 23 to $40 \%$ higher yields in SC 307 and $\mathrm{SC} 212(\mathrm{P}=0.05)$. These lines showed bacterial whorl blight resistance and give a good idea of the reaction of sorghum lines to fungicides without bacterial rot and with rust susceptibility. In whorl blight susceptible moist stemmed TAM 428 and SC 120 , yield losses of 34 to $56 \%$ were recorded after fungicide treatments. These lines are susceptible to bacterial top and stalk rot but rust resistant. These results stress the importance of genotype by pesticide interactions and pesticide side effects.

The juicy stem trait appeared to be the phenotypic character most associated with bacterial whor blight. This trait is often considered beneficial for its association with nonsenescence and increased resistance to stalk diseases which attack senescent tissues. About $20 \%$ of germ plasm lines have the moist stalk character. Screening a large number of moist stemmed germplasm lines would be useful for discovering a new mechanism of bacterial whorl blight resistance. This research would allow continued use of moist stemmed germ plasm under conditions favoring severe bacterial whorl blight.

It has been suggested that the lack of emphasis on bacterial diseases in sorghum is partly due to insufficient diagnosis (9). We agree and suggest bacterial diseases are becoming more important as agro-ecosystems are modified for high yields. Besides, fungicide sprays, growth stimulants, high nitrogen fertilization, and increased irrigation may all predispose erops to higher incidence and severity of bacterial diseases. Cultural changes could transform minor pathogens into major ones of economic importance.

Because the major goals of plant breeding are high yield, quality, and resistance to common pests, there is a tendency to overlook resistance to minor diseases. The importance of specific diseases can rapidly change as the genotypes of commercial varieties shift. Minor diseases can become major diseases when major diseases are genetically controlled and susceptibility of crops to minor diseases is not considered.

Antibiotics are useful in selective media for pathogen study, as diagnostic aids, and in some cases as control agents. Because of their medical importance, antibiotics should be considered a last resort in plant disease control. Future whorl blight control studies, besides concentrating on genetic resistance, should emphasize cultural control modifying crop management practices to reduce disease spread.

\section{RESUMEN}

\section{Erwinia chrysanthemi: una enfermedad del tallo $y$ el verticilo en el sorgo}

Una pudrición blanda, de mal olor, se detectó afectando los tallos y hojas del sorgo en Isabela, Puerto Rico en 1985. La bacteria de cogollos 
enfermos se aisló y se utilizó para inocular sorgo, maíz y caña en pruebas de campo $y$ en papa $y$ piña in vitro. Las pruebas de patogenicidad y fenotípicas sugieren a Erwinia chrysanthemi p.v. zeae como la causa de la enfermedad. Se probaron 22 antibib́ticos para controlar el patógeno in virro. Senociclina, cloramfenicol, kanamicina, tetraciclina, amitracina y tobramicina fueron los más eficaces, mientras que la mayoría de los miembros de la familia de las penicilinas fueron ineficaces contra la bacteria. Los sorgos enanos (TAM 428 y SC 120) con tallos dulces $y$ húmedos se afectaron severamente después de tratarse con fungicidas foliares. El promedio de incidencia visible de la enfermedad alcanzó $25 \%$. Las pérdidas en rendimiento fueron de 34 a $56 \%$. Los sorgos enanos de tallo seco (SC 307 y SC 212) mostraron menos del $5 \%$ de la enfermedad y ninguna pérdida en rendimiento.

\section{LITERATURE CITED}

1. Bradbury, J. F., 1970. Isolation and preliminary study of baeteria from plants. Rev. Plant Pathol. 49 (5): 213-18.

2. Dickey, R. S., 1979. Evwinia chrysanthemi: A comparative study of phenotypic properties of strains from several hosts and other Erwinia species. Phytopathology 69: $324-29$.

3. Dye, D. W., 1968. A taxonomic study of Erwinia. I. The "amylovora" group. N. Z, J. Sei. 11: 590-607.

4. Hartman, J. R. and A. Kelman, 1973. An improved method for inoeulation of eorn with Envinia spp. Phytopathology 63: 658-63.

5. Kelman, A. and R. S. Diekey, 1980. B. Erwinia 2 . Soft rot or "carotovora" group. In: Laboratory Guide for Identification of Plant Pathogenic Baeteria. N. W. Schaad (Ed). Am. Soc. Phytopathol., St. Paul, Minnesota.

6. King, S. B., 1972. Diseases and their control. In: Sorghum in the Seventies. N. G. P. Rao and L. R. House (Ed). Oxford Publishing Co., New Delhi.

7. Lelliott, R. A., 1974. Description of the species of the genus Envinia. In: Bergey's Manual of Determinative Bacteriology. R. E. Buchanan and N. E. Gibbons (Ed). The Williams \& Wilkins Co., Baitimore, MD.

8. Society of American Bacteriologists, 1957. Mamual of Microbiological Methods. MeGrawHill Book Co., New York.

9. Thompson, S. W., D. C. Hilderbrand and M. N. Schroth, 1981. Identification and nutritional differentiation of the Erwinia sugar beet pathogen from members of Erwinia carotovora and Erwinia chryssanthemi. Phytopathology 71: 1037-042. 
